\title{
How Sovereign Is a State From Foreign Intervention? Gambia as a Case Study
}

\author{
Omodanisi Kemi Beatrice \\ Correspondence: Omodanisi Kemi Beatrice, Research Fellow II, Nigerian Institute of Advanced Legal Studies, Akoka, \\ Lagos, Nigeria.
}

Received: March 19, 2019

doi:10.11114/ijlpa.v2i2.4155
Accepted: July 1, 2019

Online Published: August 13, 2019

URL: https://doi.org/10.11114/ijlpa.v2i2.4155

\begin{abstract}
This paper examines to what extent is Gambia sovereign from foreign intervention. It considers the legality or otherwise of ECOWAS' military intervention in the recent post-election/ political crisis in Gambia. Bearing in mind that national sovereignty in international law is not absolute as International Humanitarian Law, Human Right and International Criminal Law have provided exceptions, this paper highlight situations which permit foreign intervention in a state and considers the various argument of writers on the legality/illegality of ECOWAS' military intervention in Gambia. The paper argues that ECOWAS' military intervention lacks the requisite authorisation of the UN Security Council who by its resolution permitted the application of political measures only. ECOWAS also failed to meet the requirement for the application of Responsibility to Protect (R2P) in Gambia. More so, intervention on the basis of restoring democracy is void of legal backing as the enabling protocol permits ECOWAS to apply sanctions on member-state where democracy is abruptly brought to an end. On the whole, this paper concludes that though ECOWAS' military intervention is justifiable in view of the situation in Gambia, it however lacked the requisite legal backing. The paper recommends that in situations where intervention is not based on humanitarian reason to necessitate the application of R2P, military intervention should have the requisite authorisation of the UN Security Council and the application of force should be the last option having exhausted all other means of dispute resolution.
\end{abstract}

Keywords: national sovereignty, non-intervention, Gambia, Economic Community of West African States (ECOWAS), military intervention

\section{Introduction}

National sovereignty is an old phenomenon that is well grounded in international law. This concept is based on the assumption that international order can be achieved and maintained where states respect each other's sovereignty and adhere to the norm of non-intervention in the internal affairs of one another. Respecting the sovereignty of each state forms a basis of global covenant which acts as a basis of the foundation of international order. ${ }^{1}$

Having originated from the Peace of Westphalia 1648, a treaty which was drawn up to end the thirty years war in Europe, ${ }^{2}$ history has it that the Pope as well as political leaders of Western Europe were involved in this treaty that permitted the prestigious office of the Pope to be utilized in granting leaders of proto-nation states authority to exercise power within their national borders. ${ }^{3}$

National sovereignty recognizes territorial borders, the monopoly of legitimate violence within these borders as well as the responsibility to provide security and basic condition of livelihood to citizens of the country. ${ }^{4}$ The concept of national sovereignty gained prominence in the nineteenth and twentieth centuries as a result of global spread in Asia, Latin America, Africa and Middle East. ${ }^{5}$

\footnotetext{
${ }^{1}$ Robert J. (2000).The Global Covenant: Conduct in the World of States (1st ed.) England: Old University Press. 30.

${ }^{2}$ Goodman L W. (1993). Democracy, Sovereignty and Intervention. 9 American University Law Review 27.

${ }^{3}$ Ibid.

${ }^{4}$ Appaduria A (2015, 16th December) Key Note Lecture on UN Conference on Refugees. Paper presented at UN Conference. Retrieved from http://www.unhcr.org/5671644f54b.pdf

${ }^{5}$ Ibid.
} 
With the awakening of national sovereignty, situations have arisen, where sovereign states under the guise of sovereignty perpetrate wrongs on its own people. Example of this is during World War II, where over six million Jews were murdered by Adolf Hitler in the Holocaust. The respect for the nation's sovereignty was a reason why other nations failed in preventing such atrocities against the German Jews. ${ }^{6}$

However, with the birth of the United Nations and the adoption of its charter, covenants and other instruments, the notion of absolute sovereignty no longer hold sway. International Humanitarian Law, Human Right and International Criminal Law have set limits on absolute sovereignty of nations.

Happenings around the world particularly in Africa reveal that some political leaders are yet to accept the fact that the right of their citizens is not at their mercy. International community and regional organisation would not hesitate to interfere in their supposed 'national sovereignty' so as to protect the right of their citizens. However, the legality of such intervention becomes an important issue for consideration. The recent happening in Gambia during her December 2016 election and ECOWAS' intervention have been queried especially as it relates to the legality. Issues arising from the legality/illegality of ECOWAS' intervention in the election are the main crux of this paper.

This paper commences with this introduction. It afterwards clarifies some concept that relates to the paper. It further considers the legal framework for national sovereignty and non-intervention after which it highlight limitations to national sovereignty. Furthermore, it analyses critically the issue of ECOWAS' military intervention in Gambia noting various arguments on the matter. The paper finally concludes and makes recommendations.

\section{Conceptual Clarification and Legal Frameworks for Sovereignty and Non-Intervention}

\section{Conceptual Clarification}

Sovereignty

Steinberger in his definition of sovereignty considered it as a basic international legal status of a state that is not subject, within its territorial jurisdiction to the governmental, executive, legislative or judicial jurisdiction of a foreign state or to foreign law other than public international law.

Furthermore, Gevorgyan considers sovereignty to be an inalienable political and legal property of any state. ${ }^{8}$

More so, Krilov considers sovereignty as the property and the state's ability to independently, without external interference, determine its internal and external policies, provided the respect for civil and human rights, protection of minority rights and respect for international law are observed. ${ }^{9}$ Noting the importance of Sovereignty Judge Huber stated in the case of Island of Palmas arbitration thus:

"Sovereignty in the relations between states signifies independence. Independence in regard to a portion of the globe to exercise therein, to the exclusion of any state, the functions of a state...The development of international law, have established this principle of the exclusive competence of the state in regard to its own territory in such a way as to make it the point of departure in settling most questions that concern international relations. ${ }^{10,}$

In this paper sovereignty is defined as a legal expression which suggests national independence. It implies the power of a state over its citizen as well as the authority to enforce obedience to its laws and regulations.

\section{Principle of Non- Intervention}

This principle means restrain from exacting an act by use of force on another country which has equal sovereignty with others. ${ }^{11}$ It can also be viewed as restraining from act capable of denying or rupturing the idea of the principles of self-determination of a sovereign country. ${ }^{12}$

\footnotetext{
${ }^{6}$ Canadian Human Right Commission "Human Right in Canada: An Historical Perspective, State Sovereignty v. International Law". Retrieved from http://www.chrc-ccdp.gc.ca/historical-perspective/en/browseSubjects/hitler.asp

7 Steinberger H. (1987). Sovereignty, Encyclopaedia for Public International Law, (Vol. 10. p. 4140).

${ }^{8}$ Gevorgyan K. "Concept of State Sovereignty: Modern Attitude" Retrieved from http://ysu.am/files/Karen_Gevorgyan.pdf

${ }^{9}$ Ibid.

${ }^{10}$ Island of Palmas Case (1928) 2 RIAA 829, 838.

${ }^{11}$ Nicaragua v. USA 1986 I.C.J 14.

${ }^{12}$ Ibid.
} 
Kmacioglu ${ }^{13}$ noted that the principle of non-intervention logically complements the principle of sovereignty.

In this paper, the principle of Non- intervention can be seen as a cardinal principle of contemporary international law, which is aimed at prohibiting not only armed intervention but all direct and indirect intervention in the domestic affairs of a sovereign state.

\section{Responsibility to Protect (R2P)}

The Global Centre for the Responsibility to Protect in its analysis of R2P sees it as a collective responsibility on the international community that is aimed at ensuring that the international community acts in the face of genocide, ethnic cleansings, war crimes and crimes against humanity. ${ }^{14}$

\section{Legal Frameworks Protecting National Sovereignty and Non -Intervention}

The legal frameworks protecting national sovereignty are codified in the United Nations (UN) Charter and some regional instruments.

\section{United Nations (UN) Charter}

The UN charter by the express provision of Article 2(4) guarantees the sovereignty of nation- state in that it prohibits all member states from using force or the threat of force against territorial integrity or political independence of any state.

For ease of reference the said article is reproduced thus:

"All Members shall refrain in their international relations from the threat or use of force against the territorial integrity or political independence of any state, or in any other manner inconsistent with the purposes of the United Nations."

Furthermore, by the import of Article 2(7) of the UN Charter, the UN is restrained from intervening in matters that is essentially within the domestic jurisdiction of any state except for the application of enforcement measures under the charter.

\section{United Nations General Assembly Resolution 2131 (1965) regarding Declaration on admissibility of intervention in the Domestic Affairs of State and the Protection of their Independence and Sovereignty. ${ }^{15}$}

This is another legal frame work that seeks to protect national sovereignty. By this resolution, the General Assembly declared that no state has the right, directly or indirectly, for any reason whatsoever to intervene in the internal or external affairs of any states.

This resolution prohibits what so ever form of intervention be it armed intervention and all other forms of interference or attempted threats against the personality of the state or against its political, economic, and cultural elements. ${ }^{16}$

Furthermore, the resolution discourage state from using or encourage the use of economic, political or any other type of measures to coerce another state in order to obtain from it, the subordination of the exercise of its sovereign rights or to secure advantages of any kind. It also prohibits a state from organizing, assisting, fomenting, inciting or tolerating subversive terrorist or armed activities directed toward the violent overthrow of the regime of another state, or interference in civil strife in another state. ${ }^{17}$

\section{United Nations General Assembly Resolution 2625 (1970) ${ }^{18}$}

This instrument provides a principle on friendly relations and co-operation among states. Apart from reaffirming the customary international law on non-intervention which imposes a duty on states to refrain in its international relations

${ }^{13}$ Kmacioglu M (2005) The Principle of Non-Intervention at the United Nations: The Charter Frame Work and the Legal Debate. Retrieved from

https://sam.gov.tr/the-principle-of-non-intervention-at-the-united-nations-the-charter-framework-and-the-legal-debate

${ }^{14}$ Global Centre for Responsibility to Protect (2015) The Responsibility to Protect: A background briefing. Retrieved from http://www.globalr2p.org/media/files/r2p-backgrounder.pdf

${ }^{15}$ General Assembly Resolution 2131 (XX) of 21 December 1965 Declaration on the Inadmissibility of intervention in the Domestic Affairs of State and the Protection of their Independence and Sovereignty. Retrieved from http://legal.un.org/avl/pdf/ha/ga_2131-xx/ga_2131-xx_e.pdf

${ }^{16}$ Resolution No. 1 General Assembly, 20th session, December 21, 1965.

${ }^{17}$ Ibid. Resolutions No. 2.

${ }^{18}$ General Assembly Resolution 2625 (XXV) on the Declaration on Principles of International Law Concerning Friendly Relations and Co-operation among states in accordance with the charter of the United Nations. Retrieved from http://www.un-documents.net/a25r2625.htm 
from the threat or use of force against the territorial integrity or political independence of state, it also reaffirmed in accordance with the UN Charter the basic importance of sovereign equality noting that the purpose of UN can only be realised if states enjoy sovereign equality. ${ }^{19}$

\section{United Nations General Assembly Resolution 50/172 ${ }^{20}$}

This resolution provides for the respect of national sovereignty and non-interference in the internal affairs of states in their electoral processes.

\section{Charter of the Organisation of American State ${ }^{21}$}

This is a regional legal frame work that protects national sovereignty. By the express provision of article $15 \& 16$ which is to the effect that no state or group of states have the right to intervene, directly or indirectly, for any reason whatever, in the internal or external affairs of any other state. It went ahead to prohibit riot as well as other form of interference against the personality of the state or against its political, economic and cultural elements. It further prohibits the use of force against the sovereign will of another state.

\section{Charter of League of Arab State ${ }^{22}$}

Article $\mathrm{V}$ of the Charter of the Arab League provides a legal backing for national sovereignty which is to the effect that any resort to force in order to resolve disputes between two or more member-states of the League is prohibited.

This provision upholds the principle of non-intervention as well as the sovereignty of member states of the League.

\section{Charter of Organisation of African Unity ${ }^{23}$}

Article III provides for member states' affirmation to adhere to the principle of sovereign equality of all member state, non-interference in the internal affairs of member states as well as respect for the sovereignty and territorial integrity of each state.

Having seen these, it is important to state at this juncture that customary international law as well as case law has accorded recognition to national sovereignty.

The decision of International Court of Justice in Nicaragua v. USA re-iterates the position of the law of non-intervention where the court stated that:

"The principle of non-intervention involves the right of every sovereign state to conduct its affairs without outside interference, though examples of trespass against this principle are not infrequent; the court considers that it is part and parcel of Customary International Law."24

As relating to customary international law, the International Court of Justice in Corfu Channel Case ${ }^{25}$ noted that "between independent states, respect for territorial sovereignty is an essential foundation of international relations."

\section{Limitation on National Sovereignty}

It is important to note that though national sovereignty is very vital in that over the years it has helped secure national borders of smaller countries from interference from larger and more developed countries, there are however limitations placed on national sovereignty.

These factors have accounted for reasons why major world powers, international and regional organisations have intervened in the domestic affairs of sovereign states. The basis for most intervention in domestic affairs is on humanitarian purpose. Chapter VII of the UN Charter provides a basis for most intervention which is acts that constitute

\footnotetext{
${ }^{19}$ Ibid. Preamble of General Assembly Resolution 2625 (XXV).

${ }^{20}$ General Assembly Resolution 50/172 on Respect for the Principle of national sovereignty and non-interference in the internal affairs in their Electoral Process. Retrieved from http://www.un.org/documents/ga/res/50/ares50-172.htm

${ }^{21}$ Charter of the Organisation of American State. Retrieved from https://treaties.un.org/doc/Publication/UNTS/Volume\%20119/volume-119-I-1609-English.pdf

${ }^{22}$ Charter of the League of Arab States. Retrieved from http://arableague.weebly.com/uploads/7/6/9/3/7693018/the_charter_of_the_arab_league.pdf

${ }^{23}$ Charter of Organisation of African Unity. Retrieved from http://www.au2002.gov.za/docs/key_oau/oau_charter.pdf

${ }^{24}$ Nicaragua v. USA (n 11).

${ }^{25}$ Corfu Channel (1949) (United Kingdom v. Albania) I.C.J. 1949 I.C.J 4. 22. Retrieved from http://www.casebriefs.com/blog/law/international-law/international-law-keyed-to-damrosche/chapter-4/corfu-channel-c ase-united-kingdom-v-albania/
} 
threat to international peace and security.

This part gives consideration to these factors.

\section{Gross Violation of Human Right}

This is the basis upon which the sovereignty of nation can be curtailed. This occurs in situations whereby the agents of the state engage in frequent violation of the fundamental human rights of its citizens. ${ }^{26}$

\section{Threat to Legitimate Order}

This particularly is a provision of the 2003 Protocol on Amendments to the Constitutive Act of the African Union (AU) ${ }^{27}$ In expanding the scope of $\mathrm{AU}$, this protocol permits intervention in the domestic affairs of member state when there is threat to legitimate order to restore peace and stability of member state.

\section{Responsibility to Protect (R2P)}

R2P was formulated and adopted in the 2005 World Submit Outcome Document at the UN World Summit. There member states unanimously accorded recognition to the responsibility to protect populations from war crimes, genocide, ethnic cleanings and crime against humanity. ${ }^{28}$ In 2009, 2010 and 2011 through the UN Secretary-General's reports this principle was re-iterated and has gained popularity. ${ }^{29}$ The principle was employed by the United Nations Security Council in response to crises in Darfur, Cote d'Ivoire, Central African Republic, Yemen, South Sudan and Mali, Syria and Libya, Democratic Republic of Congo (DRC), Kenya, Kyrgyzstan, and Guinea. ${ }^{30}$

R2P imposes obligation on states to protect their citizens from mass atrocity crimes, and in situation where they manifestly fail in doing this, the international community collectively is obliged to act. ${ }^{31}$

This is as a result of the prevalence of inter-state aggression that broke out in the 1990s within the borders of countries such as Somalia, Rwanda, and Former Yugoslavia where with, the concept of national sovereignty of these countries paralyzed the world over acting even when grave atrocities were meted out against the citizens of these countries. ${ }^{32}$

Four types of mass atrocity crimes namely: genocide, ${ }^{33}$ ethnic cleanings, ${ }^{34}$ war crime ${ }^{35}$ and crimes against humanity ${ }^{36}$ are viewed as extreme human right violation and R2P applies to these crimes.

International community going by the principle of R2P must aid states prevent these mass atrocity crimes. This can be by rendering economic assistance, rule of law reform, building of inclusive political institutions or by mediating, where violence becomes imminent.

It is important to note that it is only when mediation becomes unsuccessful in the resolution of dispute that the

${ }^{26}$ Ayoob M (2002) Humanitarian Intervention and State Sovereignty (2002) Vol 6: no 1 International Journal of Human Rights. Retrieved from http://kirstenjfisher.com/wp-content/uploads/2013/12/Ayoob-Humanitarian-Intervention-and-State-Sovereignty.pdf

${ }^{27}$ Protocol on the Amendments to the Constitutive Act of the African Union. Retrieved from

https://www.lrct.go.tz/download/treaty-convention/amendments.pdf

${ }^{28}$ Global Centre for Responsibility to Protect, (n 14).

${ }^{29}$ Ibid.

30 Bellamy A J (2015) The Three Pillars of the Responsibility to Protect. Retrieved from http://www.cries.org/wp-content/uploads/2015/09/006-bellamy.pdf

${ }^{31}$ Ibid.

${ }^{32}$ Ibid .

${ }^{33}$ Genocide is an action taken with intent to destroy in part or whole, a national, ethnical, racial or religious group. This is the subject of the 1948 Convention on Prevention and Punishment of Crime of Genocide.

${ }^{34}$ This refers to forced removal or displacement of populations, whether through the means of physical expulsion or intimidation, killing, acts of terror, rape etc.

${ }^{35}$ War crime as listed by the International Criminal Court (ICC) are such acts including torture, hostage-taking, mistreating prisoners of war, targeting civilians, pillage, rape, and sexual slavery, and the intentional use of starvation.

${ }^{36}$ Crimes against humanity as listed by the ICC statue include extermination, enslavement, deportation, torture, rape, extreme forms of discrimination and other inhumane acts of similar character intentionally causing suffering or serious injury to body or to mental or physical health. These acts when they are widespread and systematic, consciously committed as acts of policy amount to crimes against humanity. 
international community acting through the UN Security Council can use coercive measure such as sanction, arms embargoes or threatening to refer the perpetrators to the International Criminal Court (ICC). Where the state is clearly unwilling or has failed to protect its population, then the Security Council may consider the use of force. ${ }^{37}$

At this juncture, it is also important to note that R2P is not limited to the UN alone. From the adoption of R2P in 2005, the UN has emphasised the immense contribution regional and sub-regional organisations can make in the actualisation of the principle. In fact, the UN advocated for a partnership with regional organisations to be able to implement the R2P principle, especially considering that the UN Charter provides that regional organisations are also to contribute to international peace and security. ${ }^{38}$

Having seen these, R2P has three pillars thus: ${ }^{39}$

States have the primary responsibility to protect its population from genocide, war crimes, ethnic cleansing and crimes against humanity as well as from incitement of these crimes.

International community have the responsibility to assist and encourage states to fulfill their responsibility to protect, particularly by helping them to address the underlying causes of genocide and mass atrocities, build the capacity to prevent these crimes, address problems before they escalate, and encourage them to fulfill their commitments.

International community have the responsibility to take timely and decisive action to protect populations from the four crimes through diplomatic, humanitarian and other peaceful means (principally in accordance with Chapters VI and VIII of the UN Charter) and, on a case-by-case basis, should peaceful means 'prove inadequate' and national authorities are manifestly failing to protect their populations, other more forceful means through Chapter VII of the UN Charter can be applied.

It is against this background that this paper consider the Gambian situation, in a bid to decipher whether Economic Community of West African States' ( ECOWAS) military intervention can comfortably be brought under the head of ECOWAS' responsibility to protect or whether it was a mere interference in Gambia's sovereignty.

\section{Gambian Post-Election Turmoil: On the Legality or otherwise of ECOWAS' Military Intervention in Gambia}

This part considers the legality or otherwise of ECOWAS' intervention in Gambia, owing to the fact that one of the contentions of former President Yahya Jammeh was that, ECOWAS' military intervention in Gambia evaded and undermined Gambia's sovereignty.

In a bid to analyze this issue, it will be important to consider the fact of the Gambian situation.

On the $1^{\text {st }}$ of December, 2016 Gambians went to polls to change the 22 years government of former President Yahya Jammeh which was repressive, authoritarian and tyrannical. ${ }^{40}$ Having come into power as a young military officer in 1994 through a bloodless coup, he was elected in 1996, re-elected subsequently in 2001, 2006 and 2011 though in an election that did not accord to international standards of free and fair election. ${ }^{41}$ To express his desire to remain in power indefinitely, former president Yahya Jammeh in a widely quoted BBC interview stated that he would "rule this country for one billion years ..., if Allah says so." ${ }^{42}$

In the observation of Human Right Organisations, his regime was marred with high level of human right violations, torture, intimidation and disappearance of journalists and activist. ${ }^{43}$ Furthermore, his regime denied the registration of International Election Observers save for small African Union contingent as the December 2016 election approached. More so, there was no access to internet and text messages services on Election Day, due to the fact that his regime shut down all the services. ${ }^{44}$

${ }^{37}$ Global Centre for Responsibility to Protect, (n 14).

38 See Chapter VIII of the UN Charter

${ }^{39}$ World Summit Outcome Document (2005). Retrieved from

http://www.who.int/hiv/universalaccess2010/worldsummit.pdf. Paragraphs 138-139

${ }^{40}$ Hartmann C (2017) ECOWAS and the Restoration of Peace in the Gambians 52 (1) African Spectrum. 85-99. http://www.africa-spectrum.org

${ }^{41}$ Perfect, David (2010). The Gambia under Yahya Jammeh: An Assessment. 99 The Commonwealth Journal of International Affairs. 53-63

${ }^{42}$ BBC News. (12 December 2011) Gambia's Yahya Jammeh Ready for Billion-Year. BBC News

43 Amnesty International (2016) Opposition in Gambia. The Danger of Dissent. London: Amnesty International

${ }^{44}$ Hartmann C (n 40). 
After the election, surprisingly on the $2^{\text {nd }}$ of December, 2016 the opposition candidate Adama Barrow was declared the winner of the polls. In Jammeh's reaction to this he initially in his television speech conceded defeat and congratulated his opponent Adama Barrow on the success of the polls. He even went ahead to state that he would not contest the election, and vowed to return to his farm, and in his words, "to eat what I grow and grow what I eat"

The great jubilation of Gambians over the victory is indicative of the fact that they were tired of Jammeh's hard, iron-fisted regime.

However, this jubilation and celebration was short-lived as on the $9^{\text {th }}$ of December, 2016, precisely a week later in another television speech, Jammeh declared that he no longer had trust in the electoral process, as such he would be contesting the results declared by the Electoral Commission on the basis of some irregularities that were manifest. He therefore sought for a fresh election under a different electoral administration. ${ }^{46}$ To signify his control over the security apparatus, on the $10^{\text {th }}$ of December, he deployed troops on the streets of Banjul, which occupied the offices of the Electoral Commission and denied staff access to the building. ${ }^{47}$

At the legal end of his term in office which was on the $18^{\text {th }}$ of January, 2017, Jammeh refused to hand over power to the new democratically elected president. This raised both domestic and international condemnation, considering that the new president elect, fearing for his life fled the country and went into hiding in Senegal. However his absence from Gambia did not prevent international community from recognizing his legitimacy. ${ }^{48}$

Under this atmosphere, ECOWAS had to take step to intervene and even prepared for a military invasion of the country. Following the inauguration of Adama Barrow as the new president at the embassy on the $19^{\text {th }}$ of January in Dakar, some Senegalese troops having surrounded the country began to march towards Banjul in a bid to threaten Jammeh. Finally Jammeh seeing the stern domestic and international action against his decision accepted to leave and went on exile on the $21^{\text {st }}$ of January, 2017 which as such led to Borrow's assumption of office at the capital city on the $26^{\text {th }}$ of January, 2017. ${ }^{49}$

Having seen this, there are divergent views on the legality/ illegality of ECOWAS' intervention in Gambia. While some writers applauded ECOWAS' timely intervention in Gambia, others view such action as illegal, not only invading Gambia's sovereignty but displaying a show of ego and power by this sub-regional organisation.

To start with, Haatman while noting that Gambia is a member of ECOWAS from 1975 stated further that ECOWAS has the mandate to promote democracy and good governance and to adopt R2P as empowered by the revised ECOWAS treaty (1993), ${ }^{50}$ Protocol on the Mechanism for Conflict Prevention $(1999)^{51}$ and the Protocol on Democracy and Good Governance (2001). ${ }^{52} \mathrm{He}$ noted further that though these instruments mandate ECOWAS to observe election in member countries, they were denied access in Gambia, as Jammeh refused to allow ECOWAS Observation team monitor the December 2016 presidential election. ${ }^{53}$ He noted also that when Jammeh initially conceded defeat, ECOWAS together with some AU and UN official representatives for West Africa congratulated the Gambian people for having a smooth and peaceful election. However, when later Jammeh changed his position, ECOWAS quickly reacted calling on the Gambian government to "abide by its constitutional responsibilities and international obligations." More so, the government should respect fundamentally, the verdict of the ballots and ensure the security of the president elect, Adama Barrow as well as all Gambian citizens. ECOWAS' statement reveals that Jammeh's action not

45 Ibid

46 Ibid. Note that on the $5^{\text {th }}$ of December, 2017, the commission re-adjusted the votes counted and reduced the number of votes won by each of the three candidates but even thereafter still confirmed Adama Barrow's victor.

47 Ibid

48 Ibid.

49 Ibid.

50 Article 4, Paragraph J of the Revised ECOWAS Treaty, 1993. Retrieved from

http://www.ecowas.int/wp-content/uploads/2015/01/Revised-treaty.pdf

51 Protocol Relating to the Mechanism for Conflict Prevention, Management, Resolution, Peace-Keeping and Security, (1999) Retrieved from http://www.chr.up.ac.za/chr_old/hr_docs/african/docs/other/ecowas4.doc

52 Protocol A/SP1/12/01 on Democracy and Good Governance Supplementary to the Protocol relating to the Mechanism For Conflict Prevention, Management, Resolution, Peacekeeping and Security (2001). Retrieved from http://www.internationaldemocracywatch.org/attachments/350_ECOWAS\%20Protocol\%20on\%20Democracy\%20and\% 20Good\%20Governance.pdf

53 Hartmann C (n 40). 
only threatens the peace of Gambia, but the whole of the sub-region in its entity. ${ }^{54}$ ECOWAS' first line of action was mediation as a delegate was sent to Banjul on the $13^{\text {th }}$ of December, 2016 but unfortunately the mediation proved abortive. ${ }^{55}$ Other attempt was made for mediation, this time around ECOWAS utilised the good offices of President Buhari and President Mahama of Nigeria and Ghana respectively, but this attempt also failed to make Jammeh change his mind. It was at the approach of the deadline which was 18 January 2017, that it became apparent that military intervention is inevitable, ${ }^{56}$ and consequently on the $14^{\text {th }}$ of January, ECOWAS' Military Intervention in The Gambia (ECOMIG) was formed. On the $18^{\text {th }}$ of January, 2017 troops (most from Senegal, with contingents from Nigeria, Ghana, Mali, and Togo) started to move towards the border of Gambia (which is surrounded by Senegalese territory), and together with Nigerian forces they implemented a naval blockade. ${ }^{57}$

In a nutshell, Hartman posited that the action of ECOWAS is legitimate, having obtained not only the approval of the AU but the UN. The UN through the Security Council unanimously approved resolution 2337, expressing its full support for ECOWAS' quest "to ensure, by political means first," that "the will of the people of Gambia expressed in the results of 1st December elections" is honoured. He however noted that the UN Security Council did not endorse military action according to Chapter VII of the UN Charter. ${ }^{58}$ As such, the legal mandate it derived from the aforementioned instruments is a basis for the exercise of the power of intervention into the Gambian situation in a bid to restore democracy.

In addition, another writer Jallow ${ }^{59}$ noted that Jammeh's total disregard for international organisations and states such as AU, ECOWAS, EU, US and UK was quite worrisome as in several occasions he insulted them. He also noted that his cruel, brutal and animalistic behaviour justifies such military intervention. He asserted that Jammeh's administration is tyrannical, extravagant, repulsive and tribalistic. In his words,

"Yahya Jammeh is stuck to the past; in the world of archetypal dictators, tyrants and military rulers, who graduated into believing their indispensability and supreme right to not be accountable to justice and the laws of the lands."

Having highlighted most atrocities and sufferings Gambians have suffered under his leadership, he concluded by stating that ECOWAS' intervention is needed as well as timely.

In addition to these, an opinion expressed by $\mathrm{Nkea}^{61}$ on the legality of ECOWAS' action reveals that it must be measured in accordance to applicable rules of international law as it relates to the use of force between states. This he stated must be weighed against Article 2(4) of the UN Charter that prohibits the use of force and expressed the rule of non-intervention recognized customarily under international law. He however noted that military intervention that is aimed at restoring or upholding a democratically elected government is exclusion to this rule as ECOWAS pro-democratic intervention would rather support the territorial sovereignty of Gambia by enforcing the political will and sovereignty of Gambians which would otherwise be violated by the hold on power by Jammeh. ${ }^{62}$

Having seen these, in a bid to have a fair standing on the legality or otherwise of the intervention, this paper gives consideration to opinion of writers who vehemently opposes ECOWAS' intervention on the basis that it undermined the sovereignty of Gambia.

\footnotetext{
${ }^{54}$ Fiftieth Ordinary Session of the ECOWAS Authority of Head of States and Government (2016). Retrieved from http://www.ecowas.int/wp-content/uploads/2016/12/Communiqu\%C3\%A9-Final_50th-Summit_Abuja_Dec-16_Eng. pdf

${ }^{55}$ Ibid.

${ }^{56}$ Vanguard (14 January 2017). Gambian Crisis Takes Centre Stage at Mali Summit. Vanguard. Retrieved from www.vanguardngr.com/2017/01/gambian-crisis-takes-centre-stage-mali-summit

${ }^{57}$ Hartmann C (n 40).

${ }^{58}$ Ibid.

59 Jallow M K. Gambia: Why Intervention is Necessary. Retrieved from

http://www.wisafricana.com/gambia-why-ecowas-intervention-is-necessary-perhaps-even-inevitable-as-yahya-jammehtests-the-bodys-resolve/

${ }^{60}$ Ibid.

${ }^{61}$ Nkea E (January 3 2017). Transcending the Post-Election Crisis in the Gambia: A Politico-Legal Perspective. SMBC News. Retrieved from

https://gambia.smbcgo.com/2017/01/03/transcending-post-election-crisis-gambia-politico-legal-perspective/

${ }^{62}$ Ibid.
} 
Narmer ${ }^{63}$ in his thought raised vital proposition that this paper considers. To start with, he posited that ECOWAS' intervention was in a bid to back up Senegal's invasion of Gambia, which is Senegal's neighbour. He noted that this is a tectonic shift in the business of war that is gradually taking shape across the continent of Africa in general. Many of the West African states that demanded invasion by Senegal have experienced numerous military coups carried out by the military and have been involved in counter-insurgency operations yet there was no intervention from neighbouring states or even sub-regional organisation, so why is the Gambian situation so peculiar? In addition, it is his averment that ECOWAS itself lacks the mandate to intervene in any nation in the region for any reason save to ensure the protection of citizens in the case of humanitarian intervention crisis, which the Gambian situation in his opinion do not fit in. In addition, he averred that 86 per cent of Gambian's foreign trade is conducted with Britain and EU states, tourism as such constituting at least 40 per cent of Gambian's hard currency earning. As such, diplomatic pressure would be a better pragmatic tool against Jammeh considering the fact that farming and fishing constitute the source of earning of the people. Imperialist governments would have placed serious sanction on Jammeh without necessarily intervening in the affairs of the country. ${ }^{64}$

He further analyzed a close connection between United States (U.S) and Senegal with Senegal's army representing a U.S military outpost in West Africa. In his view, Senegal should not be seen as a representative for ensuring or restoring democracy under ECOWAS tutelage. To him, the intervention is part of a neo-colonialist project to guarantee the dominance of Washington in regional military affairs. Jammeh was not the only African leader whose government was in power for so long, for instance Paul Biya, Cameroon's president has been in power for 33 years, while Djibouti's Ismail Omar Gaelleh and Uganda's Yoweri Museveni have been in power for more than a decade with no sign of stepping down. ${ }^{65}$ It is however questionable that ECOWAS did not intervene in these countries to unseat their presidents who have been in power for so long. He posited finally that most nations that backed Senegal's illegal invasion of Gambia have worst atrocities going on in their countries. For Instance, Nigeria has being battling with the menace of Boko Haram and the havoc they keep causing. The issue of finding Chibok Girls is still lingering, and instead of concentrating on these issues, the Buhari-led government is more concern in invading Gambia a nation which posed no threat to regional stability of West Africa. ${ }^{66}$

Another position on the illegality of ECOWAS' intervention in Gambia is expressed in the opinion of Akpan ${ }^{67}$ It is his averment that Jammeh's argument on the illegality of ECOWAS' planned action was the right position of the law. The basis for his averment is hinged on the fact that ECOWAS lacked the legal basis for such intervention, because the original or revised ECOWAS treaty did not empower ECOWAS to establish a standby military force or deploy such force against the territorial integrity of any member state. He noted further that on the contrary, article 4(d) of ECOWAS' treaty clearly commits member states to uphold the principle of non-aggression between states. More so, supporters of ECOWAS might want to use article 4 (j) of ECOWAS' treaty as the basis for authority in that such empowered it to "promote and consolidate a democratic system of governance in each member state as envisaged by the Declaration of political Principles adopted in Abuja on 6 July 1992" in the region. However, this article did not identify expressly any means of promoting and consolidating a democratic system of governance. In the failure of an express laid down rule, it means states cannot be bound by implied obligation in a treaty based on the rule of pacta sunt servanda. ${ }^{68}$

Akpan made a comparison between ECOWAS' intervention in Sierra Leone and Liberia as against what was operational in Gambia. He noted that in Sierra Leone, ECOWAS had to intervene to put an end to the brutal civil war that was fast becoming a Hiroshima. That is, ECOWAS' intervention was based on humanitarian ground. In comparison to Gambia, this was not the situation, in fact, Jammeh was careful not to unleash soldiers on the citizenry. Finally, he noted that only African Union is empowered to intervene in the internal affairs of a member state on the basis of war crime, genocide and crime against humanity. ${ }^{69}$

\footnotetext{
${ }^{63}$ Narmer A (2017). Mr Jemmah Leaves The Gambia Amidst An Illegal ECOWAS-Backed Senegalese Invasion Grand Mother Africa.

http://grandmotherafrica.com/mr-jammeh-leaves-gambia-amidst-illegal-ecowas-backed-senegalese-invasion/

${ }^{64}$ Ibid.

${ }^{65}$ Peter Dorrie. (2015) U.S Doubles on Down Failed Military Strategy in Africa. World Politics Review http://www.worldpoliticsreview.com/articles/17192/u-s-doubles-down-on-failed-military-strategy-in-africa

${ }^{66}$ Ibid.

${ }^{67}$ Akpan A (2017). The Illegality of ECOWAS Planned Military Intervention in Gambia. Retrieved from http://thenigerialawyer.com/the-illegality-of-ecowas-planned-military-intervention-in-the-gambia/

${ }^{68}$ Ibid.

${ }^{69}$ Ibid.
} 
Having considered the various opinions, this paper will start by noting that it is the Security Council of the United Nations that is armed with the function of maintaining international security and peace. ${ }^{70}$ By the provision of article 52 (1) of the UN Charter, regional organisations or agencies are not precluded from dealing with matters relating to the maintenance of international peace and security which must be in consonance to the purpose and principle of the UN Charter. However, by the import of article 53 regional organisations require the authorization of the Security Council to be able to carry out any enforcement action.

The question that arises at this juncture is was ECOWAS authorised to intervene militarily in Gambia? To answer this, it is important to peruse Resolution 2337 on Peace Consolidation in West Africa passed by the UN Security Council on the $19^{\text {th }}$ of January, 2017 to address the Gambian situation. ${ }^{71}$ The Security Council after reaffirming its strong commitment to the sovereignty, independence, territorial integrity and unity of the Islamic Republic of Gambia recalled the principles of good-neighbourliness, non-interference and regional cooperation. It further condemns the decision of Jammeh not to relinquish power and further welcomes AU and ECOWAS' decision to accord recognition to Adama Barrow as the president of Gambia as stated in the Fiftieth Ordinary Session of ECOWAS as well as the decisions of the Peace and Security Council of the African Union (AU). By the import of Paragraph 6 of Resolution 2337 of the Security Council, it expresses its full support to ECOWAS in its commitment to ensure "by political means first" the respect of the will of the people of Gambia as expressed in the results of $1^{\text {st }}$ December elections."

From the wordings of this provision, can it be said that UN Security Council expressly authorized military intervention in Gambia? Juxtaposing this situation with a similar situation in Sierra Leone in 1998, whereby the Security Council approved ex post facto the decision to return Ahmed Tejan Kabbah to power, stating that the situation in Sierra Leone constitutes a threat to international peace and security in the region and on that basis intervened on humanitarian basis. It expressly prevented the sale or supply to Sierra Leone, petroleum and petroleum products, arms and ammunition including other related weapons. ${ }^{72}$ Furthermore, in Haiti following the 1991 coup the Security Council also authorised "all necessary measures" in order to assist, in cooperation with the Organization of American States, to bring solution to the crisis in Haiti, ${ }^{73}$ as such by another resolution, it authorised the use of multinational force in Haiti. ${ }^{74}$

It is doubtful however, if Security Council authorised military invasion in Gambia. This is expressly seen in the 2017 UN Resolution 2337 which only authorized the use of 'political means first' in resolving the dispute in Gambia. As a matter of necessity, the Security Council should authorise the use of force, and this authority must precede the use of force itself. This position the ICJ echoed in Libya $v U K^{75}$ while emphasizing the need for prior Security Council's resolution and authorisation of the use of force. The ICJ declined to give retroactive effect to a Security Council's resolution, which was a resolution adopted by the Security Council after the deployment of force noting that this cannot permit the use of force. The essence of this prior authorization is to secure the UN's collective security system and safeguard the Security Council while ensuring that it has effective control over non-defensive use of force and as such it follows that authorization must precede the action. ${ }^{76}$ This also ensures that the use of force is brought to the minimum and encourages conciliatory ways of resolving dispute as well as protecting the sovereignty of state against external interference into the affairs of the state. ${ }^{77}$

Another issue that questions the legality is whether the Gambian situation resulted to threat to international peace and security to permit the use of force as provided by Chapter VII of the UN Charter? A comparison of the Gambian situation with what was obtainable in Haiti reveals a lot of differences in both situations. In Haiti the Security Council

\footnotetext{
${ }^{70}$ See article 24 (1) of the UN Charter. Retrieved from http://www.refworld.org/pdfid/3ae6b3930.pdf

${ }^{71}$ Resolution 2337 (2017) Peace Consolidation in West Africa. S/RES/2337 (2017). Retrieved fromhttp://unscr.com/en/resolutions/2337

${ }^{72}$ Resolution 1132 (1997). The Situation in Sierra Leone. S/RES/1132 (1997)

https://www.un.org/press/en/2017/sc12688.doc.htm

${ }^{73}$ Paragraph 2, Resolution 841(1993). Retrieved from http://www.hartford-hwp.com/archives/43a/132.html

${ }^{74}$ S/ Res/940. Retrieved from

http://www.securitycouncilreport.org/un-documents/document/Chap\%20VII\%20SRES\%20940.php

${ }^{75}$ Libya v UK ( Preliminary Objection) 1998 9CJ Rep 9

${ }^{76}$ Christian Water, 'Security Council Control Over Regional Action' in Jochen Frowein and Rudiger Wolfrum (eds), MPYUNL, vol ( Kluwer 1997) 177.

77 Jane Stromseth, 'Rethinking Humanitarian Intervention: The Case for Incremental Change' in JL Holzgrefe and Keohane (eds), Humanitarian Intervention: Ethical, Moral and Political Dilemmas (CUP 2003) 242.
} 
interpreted the 1994 crisis as a threat to international peace and security. The 9 months de facto regime in Haiti was notorious for political and extra judicial killings by the security forces and their allies, disappearance of persons, politically motivated rapes, beatings and other mistreatment which called for humanitarian intervention. ${ }^{78}$

At this juncture, it is vital to state that military intervention can be legitimate where it is a unilateral humanitarian intervention. In other words, a state or group of states can act without the express authorization of the UN to halt atrocities perpetrated in another state. An example of this is NATO's intervention in Kosovo in 1999. While it is obvious that the prior authorization of UN Security council was not first sought and obtained, some have argued that, the intervention is legitimate on moral or humanitarian ground. ${ }^{79}$ However, the Gambian situation cannot fit into this context because the situation has not ripened to call for intervention on humanitarian ground.

Furthermore, the principle of R2P as discussed above requires international community to protect citizens from mass atrocities such as war crime, crime against humanity, genocide and ethnic cleansing, where a state has failed to protect its citizens from these crimes. However, the query here is, were there mass atrocities committed in Gambia to warrant ECOWAS' intervention? The answer is in the negative. Jammeh was not accused of war crime, crime against humanity, ethnic cleansings or genocide. Although there were prospects for commission of genocide in Gambia, for instance, in June 2016, the UN Special Adviser on the prevention of Genocide condemned Jammeh's inciting comments about the Mandinka ethnic group wherewith he threatened to eliminate them, and sees them as irresponsible and extremely dangerous. ${ }^{80}$

Finally, this paper considers the legitimacy of ECOWAS' intervention against the background of restoring a legitimate order in Gambia. By the import of the 2003 Protocol on Amendments to the Constitutive Act of the African Union (AU), ${ }^{81}$ the protocol expands the scope of AU's intervention in the territory of member state when there is threat to legitimate order to restore peace and stability to member state. ${ }^{82}$ Gambia signed this protocol, ratified/ acceded and deposited it. ${ }^{83}$ The situation in Gambia justifies AU's intervention considering that Jammeh's refusal to hand over power amounted to a threat to Gambia's legitimate order. There was need to restore peace to Gambia which was at the verge of breaking up, as it was reported that there was intense tension and thousands of Gambians were already fleeing the country to neighbouring villages and rural areas. ${ }^{84}$ Furthermore, as it relates to ECOWAS, the 2001 Protocol on Democracy and Good Governance mandates ECOWAS to deal with domestic politics of member states. This protocol which has been ratified by most member states including Gambia requires every accession to power to be in accordance with a free, fair and transparent election reflecting the principle of zero tolerance for power obtained by unconstitutional means. ${ }^{85}$ ECOWAS by this protocol is empowered to implement sanctions in an event that democracy is abruptly brought to an end by any means. ${ }^{86}$ These sanctions range from suspension of decision-making rights within ECOWAS to any other sanctions deemed appropriate by the Mediation and Security Council and the Authority of Heads of State and Government. From the wordings of this protocol, it is not stated that ECOWAS can intervene on the basis of democracy, but can only apply sanctions.

${ }^{78}$ Haiti Human Right Practices (1994). Retrieved from http://dosfan.lib.uic.edu/ERC/democracy/1994_hrp_report/94hrp_report_ara/Haiti.html

79 Alexander K W (2000). Nato's Intervention in Kosovo: The Legal Case for Violating Yugoslavia's National Sovereignty in the Absence of Security Council's Approval. http://www.hjil.org/articles/hjil-22-3-alexander.pdf

${ }^{80}$ United Nations Press Release. Statement by Adama Dieng, United Nations Special Adviser on the Prevention of Genocide, on recent inflammatory rhetoric by President Yahya Jammeh of the Gambia, targeting the Mandinka ethnic group. Retrieved from

http://webcache.googleusercontent.com/search?q=cache:4hhmLXHj-p4J:www.un.org/en/preventgenocide/adviser/pdf/2 016-06-09.Statement\%2520Gambia.final.pdf $+\& c d=2 \& h l=e n \& c t=c l n k \& g l=n g$

${ }^{81}$ Protocol on the Amendments to the Constitutive Act of the African Union. Retrieved from

https://www.lrct.go.tz/download/treaty-convention/amendments.pdf

82 Ibid. Article 4, Paragraph H.

${ }^{83}$ African Union (2016). List of Countries Which have Signed, Ratified/ Acceded to the Protocol on the Amendments to the Constitutive Act of the African Union. Retrieved from https://www.au.int/web/sites/default/files/treaties/7785-sl-amendments_to_the_constitutive_act_0.pdf

${ }^{84}$ BB C News (20 January 2017). Gambia Political Crisis: What Happens Next. BBC News Retrieved from http://www.bbc.com/news/world-africa-38650266

${ }^{85}$ Article 1a and 1b of Protocol A/SP1/12/01 on Democracy and Good Governance Supplementary to the Protocol relating to the Mechanism For Conflict Prevention, Management, Resolution, Peacekeeping and Security (n 53).

${ }^{86}$ Ibid. Article 45. 
As such, from the foregoing it is clear that the only basis that justifies intervention in Gambia is on the basis of preventing a threat to legitimate order and from the enabling law, $\mathrm{AU}$ is the organisation vested with the responsibility of intervention on such basis.

Having considered all these, this paper observes that in Africa, interventions till date have political undertone. Powerful states are always eager to intervene in the sovereignty of weaker states. This is glaring in Nigeria's role in ECOMOG In 1990 when it intervened in Liberia, Sierra Leone in 1997 as well as Guinea- Bissau in 1999.The intervention in Gambia is politically inclined considering that Jammeh recently have not gained the acceptance of regional leaders, primarily not because of his repressive rule, but due to his unreliable personal behaviour. This is manifest in some statements made by him that is regarded demeaning. For instance, he not only claimed to have cured HIV successfully and different types of cancer with his herbal remedies, but noted also that homosexuals are "vermin" and also described non-religious people as "lower than pigs." ${ }^{87}$ These statements reflect his personality which most sub-regional governments were not comfortable with.

\section{Conclusion and Recommendations}

While this paper commends ECOWAS' swift response to the Gambian situation, it however calls the legitimacy of its military intervention to question. The UN Security Council did not authorised the use of force, it only authorised intervention by political means. More so, the Gambian situation did not meet the threshold to allow intervention on humanitarian ground as none of the mass atrocities have been committed against its citizens to warrant application of R2P. In addition, intervening on the basis of upholding democracy and the rule of law is bereft of legal backing as the enabling protocol permits ECOWAS to impose sanction where democracy is or is about to be brought to an end. AU would have been the appropriate organisation to intervene on such ground as it has the mandate to intervene when there is a threat to legitimate order, peace and stability of member states.

Bearing in mind that national sovereignty is vital to the existence of a nation, which International Law tries to protect, this paper recommends the following:

1. The provision of an instrument which clearly state the basis for intervention to encompass situations like the Gambian case.

2. The exhaustion of all other peaceful means of resolution before military intervention. In Gambia for instance, the window of peaceful resolution was still open. Instead of venturing on an illegal military intervention, ECOWAS would have sought the UN Security Council's declaration that Jammeh's refusal to cede power amounts to threat to international peace and security based on the provision of article 39 of the UN's charter. Having done that, ECOWAS can seek the authorisation of the Security Council to intervene on the basis of article 53 of the UN Charter.

3. Intervention should be based on genuine suffering of citizens with no political undertone or factor. The intervention in Gambia have set a bad precedent, though justifiable but without legal backing.

\section{References}

Alexander, K. W. (2000). Nato's Intervention in Kosovo: The Legal Case for Violating Yugoslavia's National Sovereignty in the Absence of Security Council's Approval. http://www.hjil.org/articles/hjil-22-3-alexander.pdf

Amnesty International (2016). Opposition in Gambia. The Danger of Dissent. London: Amnesty International.

Appaduria, A. (2015, 16th December). Key Note Lecture on UN Conference on Refugees. Paper presented at UN Conference. Retrieved from http://www.unhcr.org/5671644f54b.pdf

Article 4, Paragraph J of the Revised ECOWAS Treaty, 1993. Retrieved from http://www.ecowas.int/wp-content/uploads/2015/01/Revised-treaty.pdf

Ayoob, M. (2002). Humanitarian Intervention and State Sovereignty. International Journal of Human Rights, 6(1)。 https://doi.org/10.1080/714003751

BBC News. (12 December 2011). Gambia's Yahya Jammeh Ready for Billion-Year. BBC News

Bellamy, A. J. (2015). The Three Pillars of the Responsibility to Protect. Retrieved from http://www.cries.org/wp-content/uploads/2015/09/006-bellamy.pdf

Canadian Human Right Commission "Human Right in Canada: An Historical Perspective, State Sovereignty v. International Law". Retrieved from http://www.chrc-ccdp.gc.ca/historical-perspective/en/browseSubjects/hitler.asp

${ }^{87}$ Loftin, Kaspar, (2017). The Smiling Coast: Fall of a Dictator, in. The World Weekly. 
Charter of Organisation of African Unity. Retrieved from http://www.au2002.gov.za/docs/key_oau/oau_charter.pdf

Charter of the League of Arab States. Retrieved from http://arableague.weebly.com/uploads/7/6/9/3/7693018/the_charter_of_the_arab_league.pdf

Charter of the Organisation of American State. Retrieved from https://treaties.un.org/doc/Publication/UNTS/Volume\%20119/volume-119-I-1609-English.pdf

Christian, W. (1998). Security Council Control over Regional Action in Jochen Frowein and Rudiger Wolfrum (eds), MPYUNL, ( Vol p. 177). Kluwer.

Corfu, C. (1949). (United Kingdom v. Albania) I.C.J. 1949 I.C.J 4. 22. Retrieved from http://www.casebriefs.com/blog/law/international-law/international-law-keyed-to-damrosche/chapter-4/corfu-chan nel-case-united-kingdom-v-albania/

Fiftieth Ordinary Session of the ECOWAS Authority of Head of States and Government (2016). Retrieved from http://www.ecowas.int/wp-content/uploads/2016/12/Communiqu\%C3\%A9-Final_50th-Summit_Abuja_Dec-16_E ng.pdf

General Assembly Resolution 2131 (XX) of 21 December 1965 Declaration on the Inadmissibility of intervention in the Domestic Affairs of State and the Protection of their Independence and Sovereignty. Retrieved from http://legal.un.org/avl/pdf/ha/ga_2131-xx/ga_2131-xx_e.pdf

General Assembly Resolution 2625 (XXV) on the Declaration on Principles of International Law Concerning Friendly Relations and Co-operation among states in accordance with the charter of the United Nations. Retrieved from http://www.un-documents.net/a25r2625.htm

General Assembly Resolution 50/172 on Respect for the Principle of national sovereignty and non-interference in the internal affairs in their Electoral Process. Retrieved from http://www.un.org/documents/ga/res/50/ares50-172.htm

Gevorgyan K. "Concept of State Sovereignty: Modern Attitude" Retrieved from http://ysu.am/files/Karen_Gevorgyan.pdf

Global Centre for Responsibility to Protect (2015). The Responsibility to Protect: A background briefing. Retrieved from http://www.globalr2p.org/media/files/r2p-backgrounder.pdf

Goodman, L W. (1993). Democracy, Sovereignty and Intervention. 9 American University Law Review, 27.

Haiti Human Right Practices (1994). Retrieved from http://dosfan.lib.uic.edu/ERC/democracy/1994_hrp_report/94hrp_report_ara/Haiti.html

Hartmann, C. (2017). ECOWAS and the Restoration of Peace in the Gambians, 52(1). African Spectrum, 85-99. https://doi.org/10.1177/000203971705200104

Island of Palmas Case (1928). 2 RIAA 829, 838

Jallow, M. K. Gambia: Why Intervention is Necessary. Retrieved from http://www.wisafricana.com/gambia-why-ecowas-intervention-is-necessary-perhaps-even-inevitable-as-yahya-jam meh-tests-the-bodys-resolve/

Jane, S. (2003). Rethinking Humanitarian Intervention: The Case for Incremental Change in JL Holzgrefe and Keohane (Eds), Humanitarian Intervention: Ethical, Moral and Political Dilemmas, (p 242) CUP.

Kmacioglu, M. (2005). The Principle of Non-Intervention at the United Nations: The Charter Frame Work and the Legal Debate. Retrieved from

https://sam.gov.tr/the-principle-of-non-intervention-at-the-united-nations-the-charter-framework-and-the-legal-deb ate

Narmer, A. (2017). Mr Jemmah Leaves The Gambia Amidst An Illegal ECOWAS-Backed Senegalese Invasion Grand Mother Africa.

http://grandmotherafrica.com/mr-jammeh-leaves-gambia-amidst-illegal-ecowas-backed-senegalese-invasion/

Nkea, E. (January 3 2017). Transcending the Post-Election Crisis in the Gambia: A Politico-Legal Perspective. SMBC News. Retrieved from

https://gambia.smbcgo.com/2017/01/03/transcending-post-election-crisis-gambia-politico-legal-perspective/

Perfect, D. (2010). The Gambia under Yahya Jammeh: An Assessment. 99 The Commonwealth Journal of International Affairs, 53-63. https://doi.org/10.1080/00358530903513681 
Peter, D. (2015). U.S Doubles on Down Failed Military Strategy in Africa. World Politics Review http://www.worldpoliticsreview.com/articles/17192/u-s-doubles-down-on-failed-military-strategy-in-africa

Protocol A/SP1/12/01 on Democracy and Good Governance Supplementary to the Protocol relating to the Mechanism For Conflict Prevention, Management, Resolution, Peacekeeping and Security (2001). Retrieved from http://www.internationaldemocracywatch.org/attachments/350_ECOWAS\%20Protocol\%20on\%20Democracy\%20 and $\% 20$ Good\%20Governance.pdf

Protocol on the Amendments to the Constitutive Act of the African Union. Retrieved from https://www.lrct.go.tz/download/treaty-convention/amendments.pdf

Protocol Relating to the Mechanism for Conflict Prevention, Management, Resolution, Peace-Keeping and Security, (1999). Retrieved from http://www.chr.up.ac.za/chr_old/hr_docs/african/docs/other/ecowas4.doc

Resolution 2337 (2017) Peace Consolidation in West Africa. S/RES/2337 (2017). Retrieved from http://unscr.com/en/resolutions/2337

Resolution No. (1965). 1 General Assembly, 20th session, December 21.

Robert, J. (2000). The Global Covenant: Conduct in the World of States (1st ed.) England: Old University Press 30.

Steinberger H. (1987). Sovereignty, Encyclopaedia for Public International Law, 10, 4140. https://doi.org/10.1016/B978-0-444-86241-9.50103-2

UN Charter (1945). Retrieved from https://treaties.un.org/doc/publication/ctc/uncharter.pdf

United Nations Press Release. Statement by Adama Dieng, United Nations Special Adviser on the Prevention of Genocide, on recent inflammatory rhetoric by President Yahya Jammeh of the Gambia, targeting the Mandinka ethnic group. Retrieved from

http://webcache.googleusercontent.com/search?q=cache:4hhmLXHj-p4J:www.un.org/en/preventgenocide/adviser/ pdf/2016-06-09.Statement\%2520Gambia.final.pdf $+\& c d=2 \& h l=e n \& c t=c l n k \& g l=n g$

Vanguard (14 January 2017). Gambian Crisis Takes Centre Stage at Mali Summit. Vanguard. Retrieved from www.vanguardngr.com/2017/01/gambian-crisis-takes-centre-stage-mali-summit

World Summit Outcome Document (2005). Retrieved from http://www.who.int/hiv/universalaccess2010/worldsummit.pdf. Paragraphs 138-139.

\section{Copyrights}

Copyright for this article is retained by the author(s), with first publication rights granted to the journal.

This is an open-access article distributed under the terms and conditions of the Creative Commons Attribution License which permits unrestricted use, distribution, and reproduction in any medium, provided the original work is properly cited. 